\title{
Hysteresis dependence on $\mathrm{CH} 3 \mathrm{NH} 3 \mathrm{Pbl} 3$ deposition method in perovskite solar cells
}

Silvia Leticia Fernandes, Bruna Andressa Bregadiolli, Anna Christina Véron, Frank A. Nüesch, Maria Aparecida Zaghete, et al.

Silvia Leticia Fernandes, Bruna Andressa Bregadiolli, Anna Christina Véron, Frank A. Nüesch, Maria Aparecida Zaghete, Carlos Frederico de Oliveira Graeff, "Hysteresis dependence on $\mathrm{CH} 3 \mathrm{NH} 3 \mathrm{Pbl} 3$ deposition method in perovskite solar cells," Proc. SPIE 9936, Thin Films for Solar and Energy Technology VIII, 99360B (23 September 2016); doi: 10.1117/12.2236855

Event: SPIE Optics + Photonics for Sustainable Energy, 2016, San Diego, California, United States 


\title{
Hysteresis dependence on $\mathrm{CH}_{3} \mathrm{NH}_{3} \mathrm{PbI}_{3}$ deposition method in perovskite solar cells
}

\author{
*Silvia Leticia Fernandes, ${ }^{(1,2)}$ Bruna Andressa Bregadiolli ${ }^{(2)}$, Anna Christina Véron ${ }^{(3)}$, Frank A. \\ Nüesch, ${ }^{(3)}$ Maria Aparecida Zaghete, ${ }^{(1)}$ Carlos Frederico de Oliveira Graeff ${ }^{(4)}$ \\ ${ }^{(1)}$ UNESP- Instituto de Química de Araraquara- SP, Brazil, ${ }^{(2)}$ POSMAT- Programa de Pós \\ Graduação em Ciência e Tecnologia dos Materiais, Araraquara- SP, Brazil, ${ }^{(3)}$ Empa, Swiss Federal \\ Institute for Materials Science and Technology, Laboratory for Functional Polymers, Dübendorf, \\ Switzerland, ${ }^{(4)}$ UNESP- Faculdade de Ciências de Bauru- SP, Brazil, Departamento de Física.
}

\begin{abstract}
$\mathrm{CH}_{3} \mathrm{NH}_{3} \mathrm{PbI}_{3}$ perovskite solar cells are one of the most exciting technologies in the renewable energy field, resulting in over $20 \%$ power conversion efficiency. Deep understanding of the working principle is now required to turn the high efficiency solar cells into a reliable technology. In this work we have explored the role of deposition method on the crystallinity of perovskite films and its influence on the hysteresis behavior of the current-voltage characteristics. In addition $\mathrm{Nb}_{2} \mathrm{O}_{5}$ was used as hole blocking layer and its influence is also discussed. We have found that hysteresis is strongly dependent on both; perovskite deposition method and $\mathrm{Nb}_{2} \mathrm{O}_{5}$ thickness. The ideal condition where the hysteresis is suppressed or minimized was achieved by using the sequential deposition method for the perovskite semiconductor and a hole blocking layer of $50 \mathrm{~nm}$.
\end{abstract}

Keywords: Perovskite solar cells, sequential deposition, solvent engineering, hysteresis, niobium pentoxide.

\section{INTRODUCTION}

Perovskite solar cells' power conversion efficiency has risen from $3 \%$ to more than $20 \%{ }^{1-3}$ in just four years. Though its success most of the perovskite cells present $J-V$ hysteresis. ${ }^{4-10}$ There is not a consensus regarding its cause, however the proposed origin so far include: presence of defects in perovskite materials that act as traps for electrons and holes ${ }^{11,12}$, charge accumulation at the electrodes ${ }^{13}$ as a result of ions migration or unbalanced charge extraction ${ }^{7,11}$ and ferroelectricity. One of the most critical points regarding the magnitude of the observed hysteresis is the quality of perovskite crystalline structure. The growth should be controlled in order to produce films with low density of defects leading to devices with small hysteresis. From the literature, two techniques have been mostly used to produce perovskites with high reproducibility: the sequential deposition, known as "two steps method" and solvent engineering, or "one step method". 14

The sequential deposition technique involves spin-coating of $\mathrm{PbI}_{2}$ solution followed by addition of $\mathrm{CH}_{3} \mathrm{NH}_{3} \mathrm{I}$ solution in order to form $\mathrm{CH}_{3} \mathrm{NH}_{3} \mathrm{PbI}_{3} .{ }^{15}$ Thus, in this method, a fast reaction occurs from the surface to the inner regions of lead iodide, generally resulting in uncontrolled surface roughness of the films. ${ }^{15}$ In contrast, the solvent-engineering process uses the formation of intermediate phases to retard the reaction between $\mathrm{PbI}_{2}$ and $\mathrm{CH}_{3} \mathrm{NH}_{3} \mathrm{I}$. This simple approach involves the spin-coating of a $\mathrm{CH}_{3} \mathrm{NH}_{3} \mathrm{PbI}_{3}$ solution followed by addition of a second solvent, such as chlorobenzene or toluene, to control the crystallization. ${ }^{16,17}$ Both processes have been successfully used to form methyl ammonium lead iodide films with high quality ${ }^{14,16-18}$ resulting in devices with high performance. Although the devices have shown high performance they do show commonly $J-V$ hysteresis. One alternative to reduce $J-V$ hysteresis is to use organic layers, such as PCBM, in order to improve the conductivity of the electron transport layer (ETL). We have studied the influence of the perovskite synthesis in the $J$ - $V$ hysteresis using perovskites made by one and two steps methodologies on top of the $\mathrm{Nb}_{2} \mathrm{O}_{5}$ electrons transport layer analyzing the influence of the deposition method as well the influence of the ETL materials.

\footnotetext{
Thin Films for Solar and Energy Technology VIII, edited by Michael J. Heben,

Mowafak M. Al-Jassim, Proc. of SPIE Vol. 9936, 99360B - (c) 2016 SPIE

CCC code: $0277-786 X / 16 / \$ 18 \cdot$ doi: $10.1117 / 12.2236855$
} 


\section{EXPERIMENTAL}

\subsection{Deposition of $\mathrm{Nb}_{2} \mathrm{O}_{5}$ films}

Fluorine-doped tin oxide $\left(\mathrm{F}: \mathrm{SnO}_{2}\right)$ coated glass with area of the $2.5 \mathrm{~cm}^{2}$ was etched with $\mathrm{Zn}$ powder and concentrated chloric acid. The substrates were cleaned with $2 \%$ Helmanex solution, acetone and ethanol and dried in nitrogen flux. The films were deposited by magnetron sputtering technique using a metal target of $\mathrm{Nb}(99.9 \%$ purity) in an atmosphere of $\mathrm{Ar}$ and $\mathrm{O}_{2}$. The deposition system used was a Kurt J. Lesker, equipped with a magnetron tube with diode and a power source Advance Energy RFX600 operating at $13.6 \mathrm{MHz}$. The deposition temperature was $600{ }^{\circ} \mathrm{C}$. The deposition pressure $5 \times 10^{-3}$ Torr, Ar flow of $40 \mathrm{sccm}$ and oxygen flow were $8 \mathrm{sccm}$ kept constant using different deposition times, 8 , 15,30 and 40 minutes in order to obtain films with different thicknesses.

\subsection{Synthesis of mesoporous $\mathrm{TiO}_{2}$ films}

A mesoporous layer of compact $\mathrm{TiO}_{2}$ was spin coated on top of the $\mathrm{Nb}_{2} \mathrm{O}_{5}$ film using a commercial paste (Solaronix TiNanoxide T/SP) diluted in anhydrous ethanol (1:3.5). The layers $\left(\mathrm{TiO}_{2}\right.$ and $\left.\mathrm{Nb}_{2} \mathrm{O}_{5}\right)$ were heated in air at $370{ }^{\circ} \mathrm{C}$ for 20 minutes and then at $550^{\circ} \mathrm{C}$ for 1 hour.

\subsection{Synthesis of $\mathrm{CH}_{3} \mathrm{NH}_{3} \mathrm{PbI}_{3}$ films}

The $\mathrm{CH}_{3} \mathrm{NH}_{3} \mathrm{PbI}_{3}$ films were prepared by two distinct methods:

\subsubsection{Sequential deposition ( 2 steps)}

A lead iodide solution $460 \mathrm{mg} \cdot \mathrm{mL}^{-1}$, $\left(\mathrm{PbI}_{2}\right.$ - Sigma - Aldrich 99\%) was prepared in N,N- dimethylformamide (DMF, Merck, max $0,003 \%$ water), kept under stirring at $80{ }^{\circ} \mathrm{C}$ for 24 hour. Two layers were spin coated (6000 rpm for $30 \mathrm{~s}$ ) on the mesoporous $\mathrm{TiO}_{2}$. After each deposition the film was dried on a hot plate at $70{ }^{\circ} \mathrm{C}$ for $10 \mathrm{~min}$. Then, under nitrogen atmosphere, an $8 \mathrm{mg} / \mathrm{ml} \mathrm{CH}_{3} \mathrm{NH}_{3} \mathrm{I}$ solution in 2-propanol (Merck, max $0.005 \%$ water) was deposited on the $\mathrm{PbI}_{2}$ film (4000 rpm for $\left.30 \mathrm{~s}\right)$ and treated at $100{ }^{\circ} \mathrm{C}$ for $10 \mathrm{~min}$.

\subsubsection{Solvent Engineering Method (1 step)}

A solution of $45 \% \mathrm{PbI}_{2}$ and $\mathrm{CH}_{3} \mathrm{NH}_{3} \mathrm{I}$ in DMSO (Sigma - Aldrich $\geq 99.9 \%$ ) was spin coated (1000 rpm for $10 \mathrm{~s}$ ) onto the mesoporous $\mathrm{TiO}_{2}$ film, under nitrogen atmosphere. On the last $5 \mathrm{~s}$ the anti-solvent (chlorobenzene - Sigma - Aldrich $99.8 \%$ ) was added to slow the crystallization of the perovskite phase. The films were annealed at $100^{\circ} \mathrm{C}$ for $60 \mathrm{~min}$.

\subsection{HTL, spiro-OMeTAD}

The HTL layer was deposited under nitrogen atmosphere by spin coating (4000 rpm for $60 \mathrm{~s}$ ) of a Spiro-OMeTAD (Sigma-Aldrich, 99\%) solution $72.3 \mathrm{mg}^{-\mathrm{mL}^{-1}}$ in chlorobenzene doped with $18 \mu \mathrm{l}$ of lithium bis(trifluoromethylsulfonyl)imide (Li-TFSL, Acros Organics 99\%) solution (520 mol.L $\left.\mathrm{L}^{-1}\right)$ in acetonitrile, $29 \mu \mathrm{l}$ of cobalt complex FK209 (Dyesol) solution in acetronile (sigma - Aldrich) and $29 \mu \mathrm{l}$ of tert-butylpyridine.

\subsection{Metallic contact}

Using a mask, a $70 \mathrm{~nm}$ thick gold film was thermally evaporated using an evaporator coupled to a glovebox under nitrogen atmosphere. The deposition rate was 0.2 to $1 \AA / \mathrm{s}$.

\subsection{Characterization}

The films were characterized by X-ray diffraction (XRD) using a Rigaku/RINT2000 from 10 to $50^{\circ}$. A FEG-VP Zeiss Supra 35 model was used for the FE-SEM (high resolution field emission scanning electron microscopy) measurements. Film thicknesses were determined by profilometry (Ambios XP1) and absorption measurements was performed using a Varian Cary $50 \mathrm{UV}$-vis spectrophotometer. The optical band gap values were calculated by using UV-Vis measurements and the Tauc's Equation. 
The electrical characterizations of the devices were made using a Keithley 2400 source/measure unit in the dark and under simulated AM1.5G solar irradiation of $100 \mathrm{~mW} \mathrm{~cm}^{-2}$ from a calibrated solar simulator (Spectra-Nova). The voltage sweep rate used was $5 \mathrm{mV} / \mathrm{s}$ for all measurements. Fill factor $(F F)$, open circuit voltage $\left(V_{o c}\right)$, current density $\left(J_{s c}\right)$, and energy conversion efficiency were determined from current density-voltage curves $(J-V)$.

\section{RESULTS AND DISCUSSION}

The ETLs were made in four different thicknesses in order to study its influence on device performance: 50, 70, 110 and $220 \mathrm{~nm}$ which correspond to for $8,15,30$ and $40 \mathrm{~min}$. of deposition time, respectively.

As prepared $\mathrm{Nb}_{2} \mathrm{O}_{5}$ films are amorphous. However, after thermal treatment the XRD patterns (Figure 1a) exhibit the hexagonal structure (JCPDS 28-317). Figure $1 \mathrm{~b}$ shows the FE-SEM images of $\mathrm{Nb}_{2} \mathrm{O}_{5}$ films. Its is possible to observe the substrate fully covered by a compact and dense film.

$\mathrm{TiO}_{2}$ mesoporous solution was deposited on top of the amorphous niobium oxide films and heated at $550^{\circ} \mathrm{C}$ to remove the organic components of $\mathrm{TiO}_{2}$ paste and induce $\mathrm{Nb}_{2} \mathrm{O}_{5}$ crystallization. This treatment is also believed to create chemical bonds between the two oxides for better electron extraction. As discussed in a previous work ${ }^{19}$ the use of $\mathrm{Nb}_{2} \mathrm{O}_{5}$ improves the photo-generated electron extraction from the perovskite due the alignment of the conduction band (CB) energy as shown in Figure $2 b$.
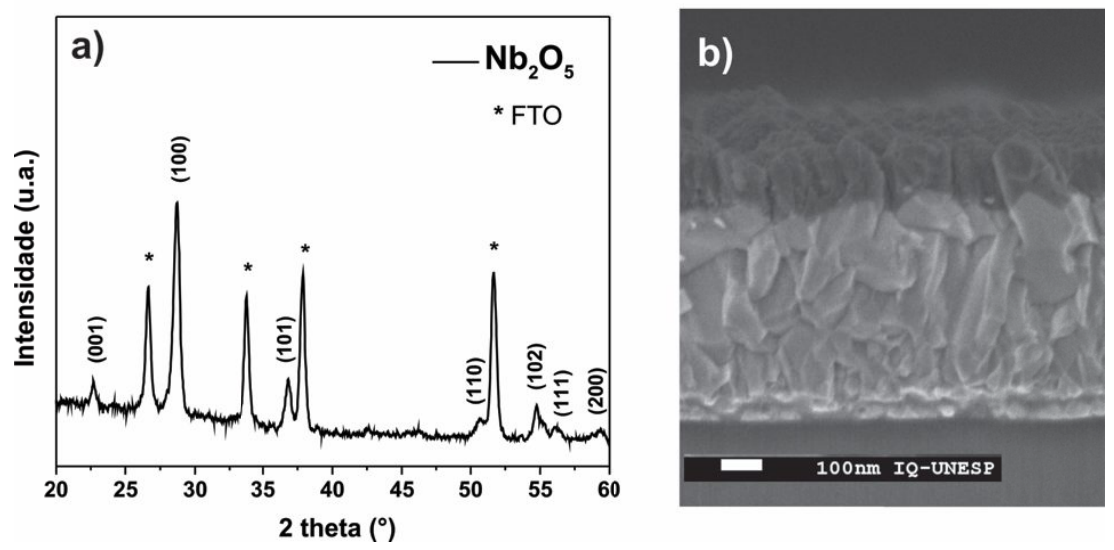

Figure 1. a) XRD and b) Cross section FE-SEM images of the $110 \mathrm{~nm} \mathrm{Nb}_{2} \mathrm{O}_{5}$ film.

a)
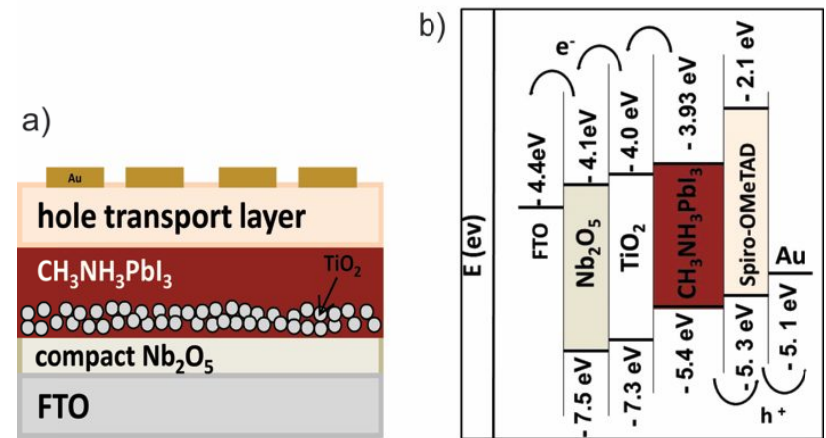

Figure 2. a) Devices structure and b) Electronic band structure of the materials used in the device. 

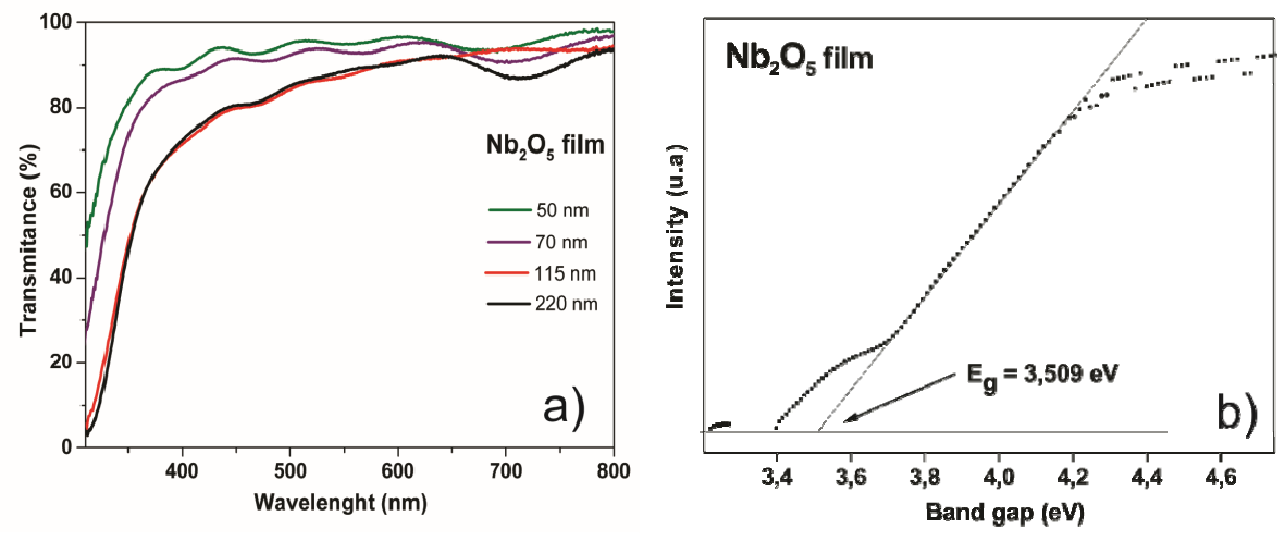

Figure 3. a) $\mathrm{Nb}_{2} \mathrm{O}_{5}$ transmittance measurements and b) $\mathrm{Nb}_{2} \mathrm{O}_{5}$ band gap calculated from optical measurement.

FTO/ $\mathrm{Nb}_{2} \mathrm{O}_{5}$ have a high optical transmittance. The transmittance values were found to be higher than $90 \%$ for all the $\mathrm{Nb}_{2} \mathrm{O}_{5}$ films studied (Figure 3a). The indirect band gap was calculated from the transmitance measurements of $200 \mathrm{~nm}$ $\mathrm{Nb}_{2} \mathrm{O}_{5}$ film and it was found to be $\sim 3.5 \mathrm{eV}$ (Figure $3 \mathrm{~b}$ ).

a)
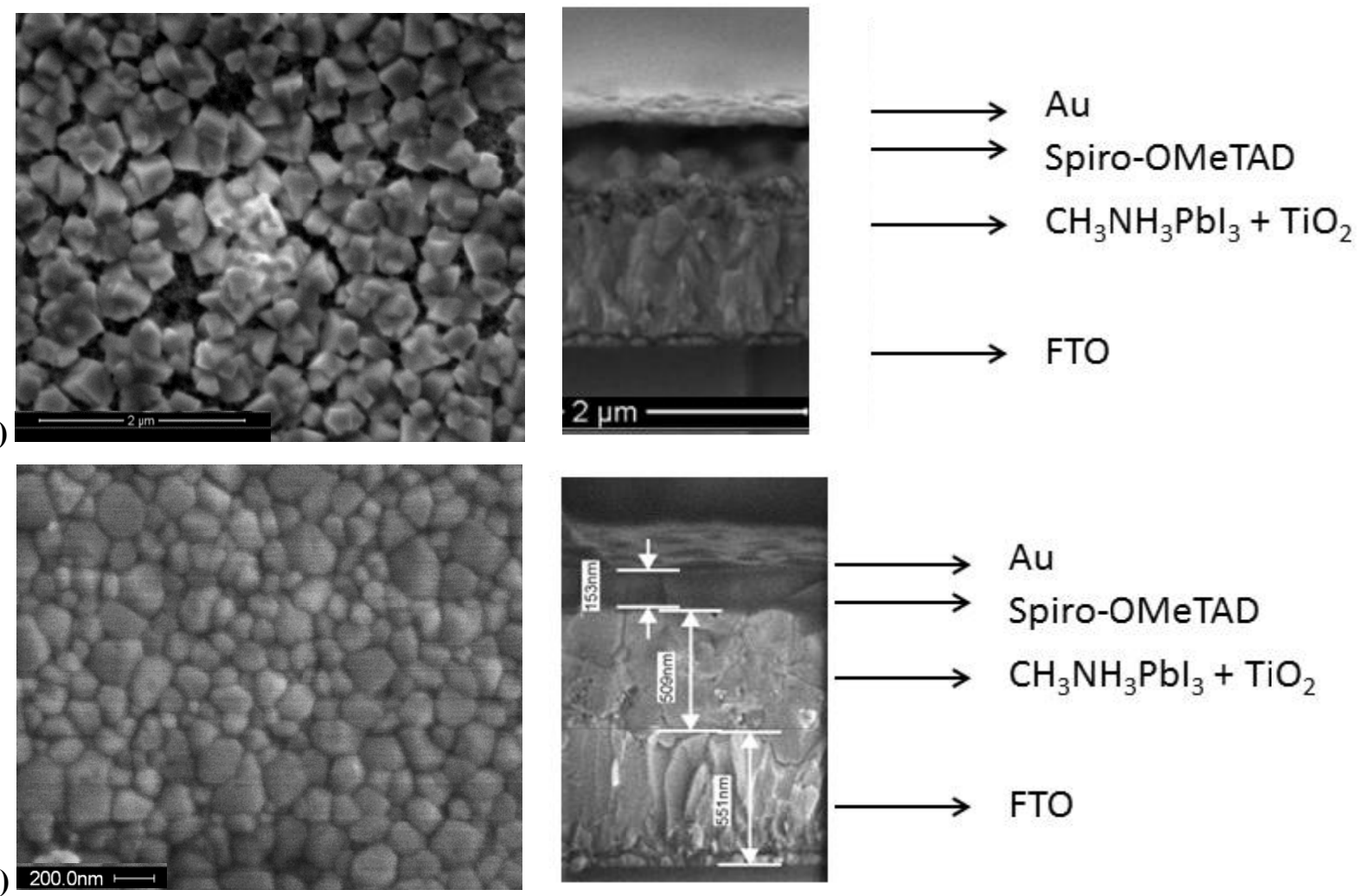

Figure 4. FE-SEM imagens (top view and cross section) of the perovskite films made by a) 2 steps and b) 1 step synthesis methodology using a $110 \mathrm{~nm} \mathrm{Nb}_{2} \mathrm{O}_{5}$ film.

SEM images of the perovskite layer prepared by both methodologies are shown in the Figure 4 . As can be seen, different process of synthesis results in different surface coverage, morphology and grain sizes. Comparing the films, it can be 
seen that the ones made by the sequential method shows a rough surface while the film deposited by solvent engineering shows a flat and dense surface. FE-SEM cross section images shows the morphology of the other materials that compose the device.

Figure 5 shows the XRD pattern of the $\beta-\mathrm{MAPbI}_{3}$ film deposited by both methods. For the two steps method a small peak in approximately $14^{\circ}$ related to $\mathrm{PbI}_{2}$ phase was observed. In this method, the crystalization happens from the surface to the inner film, resulting in an incomplete conversion of $\mathrm{PbI}_{2}$ in $\mathrm{CH}_{3} \mathrm{NH}_{3} \mathrm{PbI}_{3}$. ${ }^{14}$

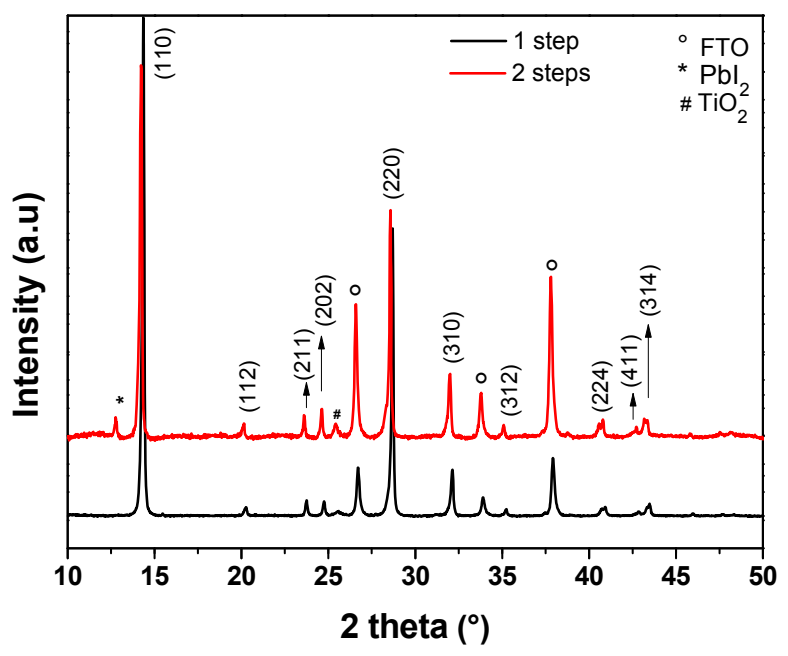

Figure 5. Indexed XRD patterns corresponding to perovskite films deposited by the one and two steps methods.

Figure 6 shows the device parameters extracted from the $J-V$ curves for cells with different $\mathrm{Nb}_{2} \mathrm{O}_{5}$ layer thickness and perovskite deposition method. In general, the devices show good performances with $V_{o c}$ of $\sim 900 \mathrm{mV}, J_{s c}$ higher than 18 $\mathrm{mA} / \mathrm{cm}^{2}$ and a $F F$ of $\sim 75 \%$, resulting in efficiency of $\sim 13 \%$ for the best cell. Although perovskite devices based in $\mathrm{Nb}_{2} \mathrm{O}_{5}$ ETL have been reported by Miyasaka et al ${ }^{20}$, the values found here are higher than that one previously reported. We attribute the better performance of our devices due the use of $\mathrm{Nb}_{2} \mathrm{O}_{5}$ and $\mathrm{TiO}_{2}$ which as already mentioned ${ }^{19}$ allows better charge extraction. Three important observations from $J-V$ results needs attention and will be discussed: 1) the high performance found in the devices made using the one step methodology, 2) the high hysteresis observed in one step perovskite based devices and 3) the hysteresis trends to decrease as the ETL thickness becomes thinner.

The best performance found in the devices made by one step methodology can be attributed by the absence of $\mathrm{PbI}_{2}$ promoted by the use of DMSO, which produces DMSO- $\mathrm{PbI}_{2}$ complexes (intermediate phase) due the strong coordinative characteristic of the solvent. This complex is able to retard the crystallization leading to a complete conversion of $\mathrm{PbI}_{2}$ into $\mathrm{CH}_{3} \mathrm{NH}_{3} \mathrm{PbI}_{3}{ }^{21}{ }^{21}$ While the use of DMF (two steps methodology) promotes a fast crystallization, resulting in the formation of $\mathrm{PbI}_{2}$ as a secondary phase, as observed in the XRD pattern, Figure 5. The secondary phase $\mathrm{PbI}_{2}$ is not as photovoltaic effective as $\mathrm{CH}_{3} \mathrm{NH}_{3} \mathrm{PbI}_{3}$. As a consequence, the $\mathrm{J}_{\mathrm{sc}}$ and $\mathrm{V}_{\mathrm{oc}}$ are smaller and the device performance is hindered. Thus, the one step method results in very compact perovskite films (see Figure 4), which can absorb more light generating higher currents compared to the two step method. 

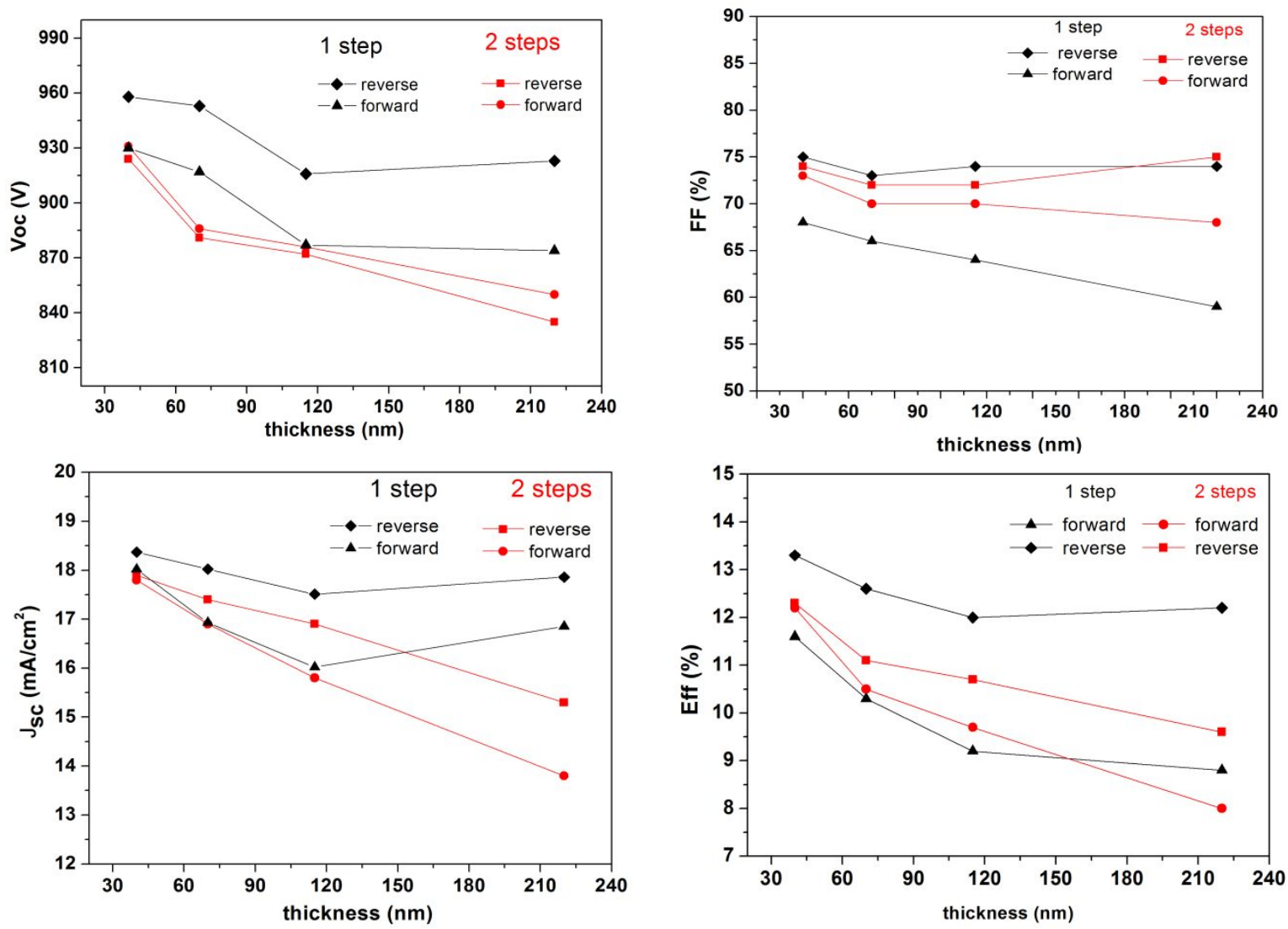

Figure 6. Parameters from the $J-V$ curves as function of the $\mathrm{Nb}_{2} \mathrm{O}_{5}$ ETL thickness of the devices constructed by using one and two steps deposition methods. It was made at least 8 devices of each one presented.

Furthermore, we have observed that hysteresis is dependent on both perovskite synthesis methodology and $\mathrm{Nb}_{2} \mathrm{O}_{5}$ thickness. Regarding the $\mathrm{Nb}_{2} \mathrm{O}_{5}$ thickness dependence, we have previously discussed ${ }^{19}$ (for two steps methodology) that higher a $R_{s}$ correlates with a difficulty in electron extraction at the electrode resulting in charge accumulation at the interfaces, causing $J-V$ hysteresis. In short, perovskite when absorber light generates electrons and holes, thus the photogenerated charges should be collected with the same rate to prevent charge accumulation. ${ }^{12}$ If the transport is hindered in the anode by using thick ETL, charges are accumulated at the interface and hysteresis is observed.

Here, we confirm the same dependence for one step deposited perovskite solar cells, i.e., the hysteresis increase with the increase in $\mathrm{Nb}_{2} \mathrm{O}_{5}$ layer thickness. Figure 7 shows the $\mathrm{J}-\mathrm{V}$ measurements and Figure 8 shows the hysteresis increase with increasing ETL thickness for both one and two steps perovskite devices.

The increase in the $\mathrm{Nb}_{2} \mathrm{O}_{5}$ thickness increases the series resistance $\left(R_{s}\right)$ of the devices, as it can be inferred from Table 1.

Table 1. Resistance calculated from the maxim power point of the forward $J-V$ curves.

\begin{tabular}{|c|c|c|c|c|}
\hline Perovskite method & $50 \mathrm{~nm} \mathrm{Nb} \mathrm{O}_{5}$ & $70 \mathrm{~nm} \mathrm{Nb}_{2} \mathrm{O}_{5}$ & $110 \mathrm{~nm} \mathrm{Nb}_{2} \mathrm{O}_{5}$ & $220 \mathrm{~nm} \mathrm{Nb} \mathrm{O}_{5}$ \\
\hline 1 step & $325( \pm 10) \Omega$ & $368( \pm 6) \Omega$ & $371( \pm 8) \Omega$ & $375( \pm 10) \Omega$ \\
\hline 2 steps & $338( \pm 12) \Omega$ & $347( \pm 14) \Omega$ & $375( \pm 12) \Omega$ & $450( \pm 21) \Omega$ \\
\hline
\end{tabular}




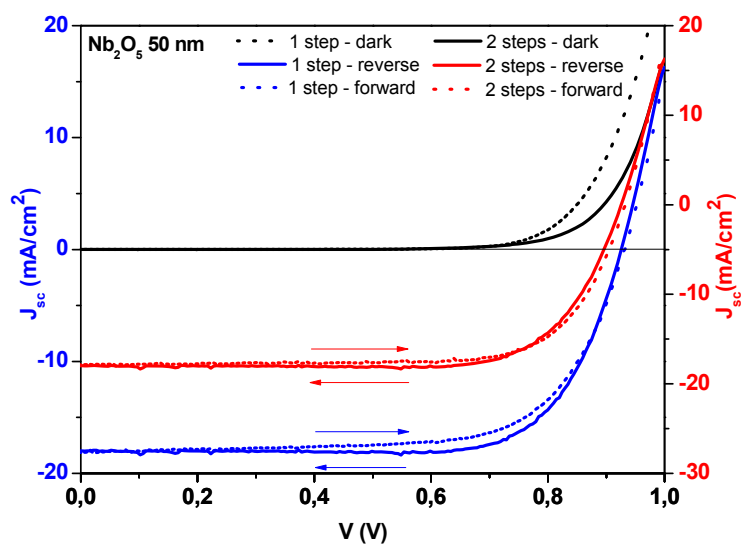

a)

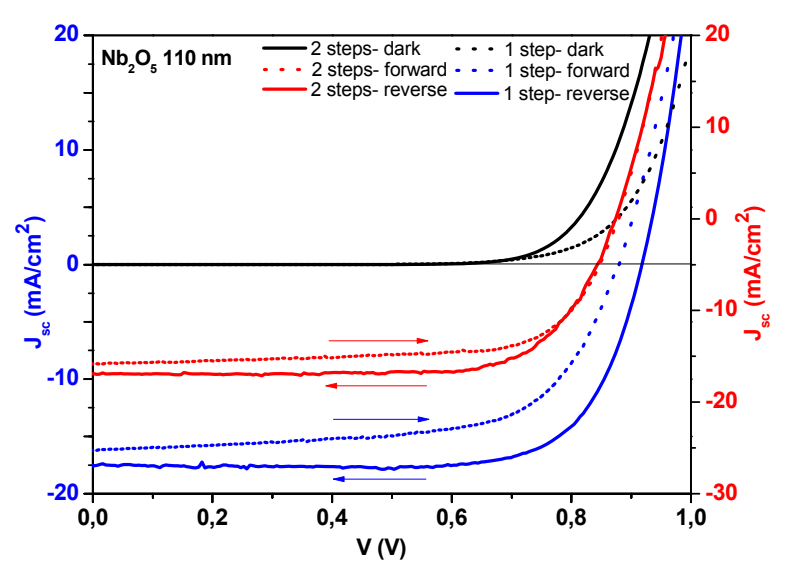

c)

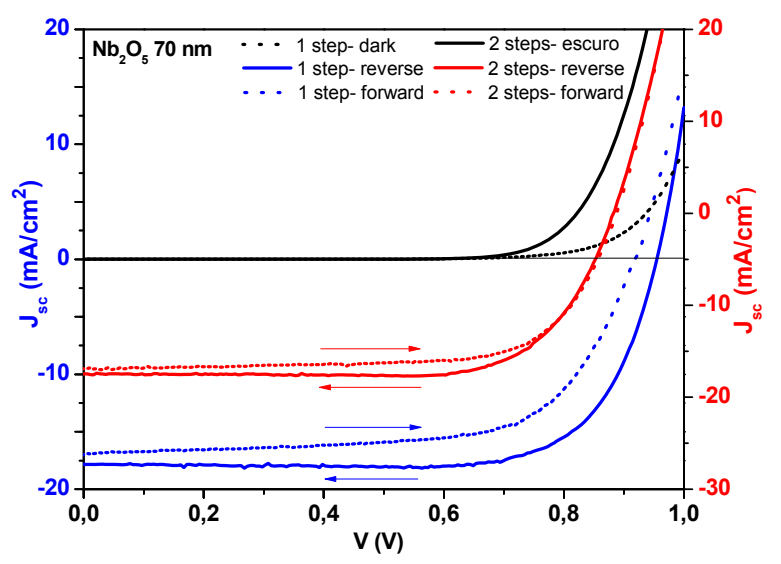

b)

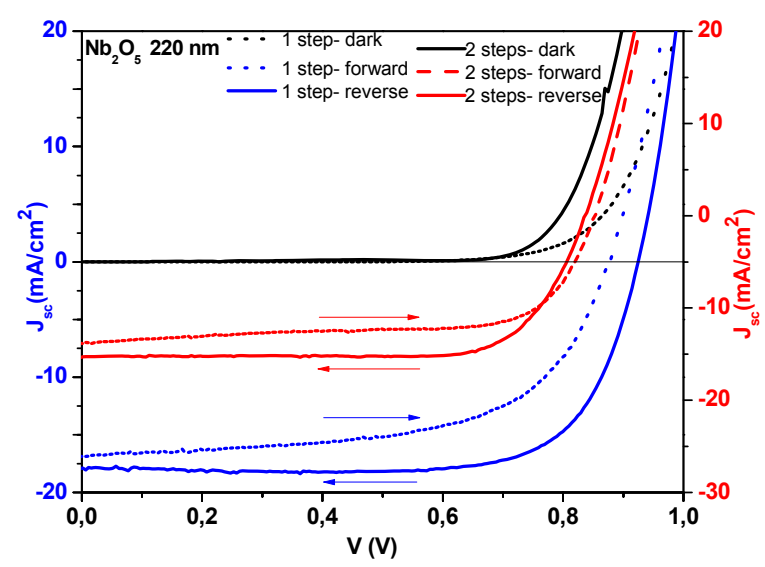

d)

Figure 7. $J$ - $V$ curves of the devices made by using the perovskite films deposited by one step (blue curves) and two steps (red curves) using different ETL thickness: a) $50 \mathrm{~nm}$; b) $70 \mathrm{~nm}$; c) $115 \mathrm{~nm}$ and d) $220 \mathrm{~nm}$.

Although the same trend in the hysteresis behavior was found for one and two steps perovskite devices, it is important to note that the $50 \mathrm{~nm} \mathrm{Nb} \mathrm{O}_{5}$ two steps perovskite devices is hysteresis-free while for the one step deposition, not. One possible explanation is that the one step methodology produces films composed by small grains, which have more grain boundary. The high amount of defect presents in the grain boundary are responsible for the hysteresis observed in $50 \mathrm{~nm}$ $\mathrm{Nb}_{2} \mathrm{O}_{5}$ thickness based one step perovskite. Although the surface of the films made by the two steps perovskite is rough, the absence of grain boundary facilitates the charge extraction preventing the J-V hysteresis. Also, as extensively discussed in the literature, the critical point to the hysteresis is the oxide (electron transport layer) / perovskite interface not the perovskite/ HTL. ${ }^{8,12}$ In addition, one cannot forget that the solvent engineering method uses DMSO as solvent. DMSO has a relatively high boiling point $\left(189^{\circ} \mathrm{C}\right)$ which makes it difficult to be removed. Traces of DMSO could be present into the perovskite films, and even if it is in small amounts, it induces defects in the crystal. As mentioned before, a large density of defects act as traps for electrons and holes, which may be filled or emptied, depending on the scan direction. Under backward scan (from the positive, i.e., open circuit, to negative, i.e., short circuit), the traps are empty due to charge transfer directly to the $p$ and $n$ contacts. Under forward scan, the traps are filled. Traps thus generates hysteresis, as it has been extensively discussed. ${ }^{5}$ Thus, considering that the one step method crystal have more defects they have also more hysteresis compared to the two step method. 


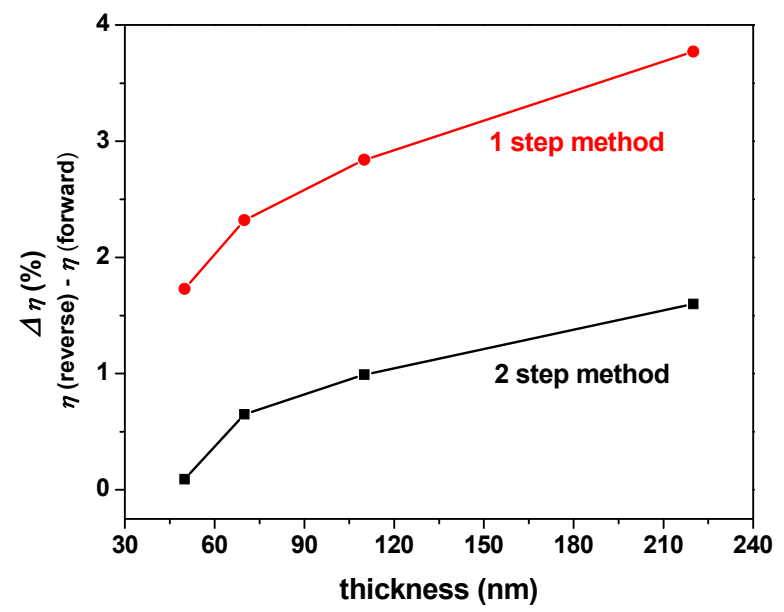

Figure 8. Difference between the conversion efficiency in the reverse and forward scans as a function of ETL thickness.

\section{CONCLUSION}

Our results show that the $J-V$ hysteresis is dependent on both the perovskite deposition method and ETL thickness. Devices made by the two steps method and $\mathrm{Nb}_{2} \mathrm{O}_{5}$ of $50 \mathrm{~nm}$ thickness in combination with the regular mesoporous $\mathrm{TiO}_{2}$ resulted in very small or unobservable hysteresis. The hysteresis increases with increasing ETL thickness and for devices that have perovskites synthesized by the two steps method. Higher ETL thickness promotes charge accumulation and the presence of grain boundaries in one step method perovskite film makes the $J-V$ hysteresis more pronounced but does not influence the performance of the devices.

\section{ACKNOWLEDGEMENTS}

The authors thanks FAPESP (Project number 2012/07745-9; 2014/23336-7; CEPID/CDMF 2013/07296-2) and CNPQ for funding, Carlos Guilherme Gonçalves de Azevedo for the help with the band gap calculation, Prof. Dr. José H. Dias da Silva for $\mathrm{Nb}_{2} \mathrm{O}_{5}$ film deposition and CBMM Company for the niobium metallic target.

\section{REFERENCES}

[1] “http://www.nrel.gov/ncpv/images/efficiency_chart.jpg.”, http://www.nrel.gov/ncpv/images/efficiency_chart.jpg, 2015, <http://www.nrel.gov/ncpv/images/efficiency_chart.jpg> (1 November 2015$)$.

[2] Kim, H.-S., Lee, C.-R., Im, J.-H., Lee, K.-B., Moehl, T., Marchioro, A., Moon, S.-J., Humphry-Baker, R., Yum, J.-H., et al., "Lead iodide perovskite sensitized all-solid-state submicron thin film mesoscopic solar cell with efficiency exceeding 9\%.," Sci. Rep. 2, 591 (2012).

[3] Kojima, A., Teshima, K., Shirai, Y.., Miyasaka, T., "Organometal halide perovskites as visible-light sensitizers for photovoltaic cells.," J. Am. Chem. Soc. 131(17), 6050-6051 (2009).

[4] Chen, B., Yang, M., Zheng, X., Wu, C., Li, W., Yan, Y., Bisquert, J., Garcia-Belmonte, G., Zhu, K., et al., "Impact of Capacitive Effect and Ion Migration on the Hysteretic Behavior of Perovskite Solar Cells," J. Phys. Chem. Lett. 6(23), 4693-4700 (2015).

[5] Snaith, H. J., Abate, A., Ball, J. M., Eperon, G. E., Leijtens, T., Noel, N. K., Stranks, S. D., Wang, J. T. W., Wojciechowski, K., et al., “Anomalous hysteresis in perovskite solar cells,” J. Phys. Chem. Lett. 5(9), 15111515 (2014).

[6] Tress, W., Marinova, N., Moehl, T., Zakeeruddin, S. M., Mohammad K., N., Grätzel, M., Nazeeruddin, M. K.., Grätzel, M., "Understanding the rate-dependent J-V hysteresis, slow time component, and aging in CH 3 NH 3 $\mathrm{PbI} 3$ perovskite solar cells: the role of a compensated electric field," Energy Environ. Sci. 8(3), 995-1004 
(2015).

[7] Wu, B., Fu, K., Yantara, N., Xing, G., Sun, S., Sum, T. C.., Mathews, N., "Charge Accumulation and Hysteresis in Perovskite-Based Solar Cells: An Electro-Optical Analysis,” Adv. Energy Mater. 1500829, 1-8 (2015).

[8] Heo, J. H., Han, H. J., Kim, D., Ahn, T. K.., Im, S. H., "Hysteresis-less inverted CH 3 NH 3 PbI 3 planar perovskite hybrid solar cells with 18.1\% power conversion efficiency," Energy Environ. Sci. 8(5), 1602-1608, Royal Society of Chemistry (2015).

[9] Unger, E. L., Hoke, E. T., Bailie, C. D., Nguyen, W. H., Bowring, A. R., Heumuller, T., Christoforo, M. G.., McGehee, M. D., "Hysteresis and transient behavior in current-voltage measurements of hybrid-perovskite absorber solar cells," Energy Environ. Sci., 3690-3698 (2014).

[10] Unger, E. L., Hoke, E. T., Bailie, C. D., Nguyen, W. H., Bowring, A. R., Heumüller, T., Christoforo, M. G.., McGehee, M. D., "Hysteresis and transient behavior in current-voltage measurements of hybrid-perovskite absorber solar cells," Energy Environ. Sci. 7(11), 3690-3698 (2014).

[11] Park, J. H., Seo, J., Park, S., Shin, S. S., Kim, Y. C., Jeon, N. J., Shin, H.-W., Ahn, T. K., Noh, J. H., et al., "Efficient CH3 NH3 PbI3 Perovskite Solar Cells Employing Nanostructured p-Type NiO Electrode Formed by a Pulsed Laser Deposition.," Adv. Mater. 27(27), 4013-4019 (2015).

[12] Heo, J. H., Sang You, M., Hyuk Chang, M., Yin, W., Ahn, T. K., Lee, S.-J., Sung, S.-J., Hwan Kim, D.., Hyuk $\mathrm{Im}, \mathrm{S}$., "Hysteresis-less mesoscopic $\mathrm{CH} 3 \mathrm{NH} 3 \mathrm{PbI} 3$ perovskite Hybrid solar cells by introduction of Li-treated TiO2 electrode," Nano Energy 15, 530-539, Elsevier (2015).

[13] Zhao, C., Chen, B., Qiao, X., Luan, L., Lu, K.., Hu, B., "Revealing Underlying Processes Involved in Light Soaking Effects and Hysteresis Phenomena in Perovskite Solar Cells," Adv. Energy Mater., 1-6 (2015).

[14] Yang, W. S., Noh, J. H., Jeon, N. J., Kim, Y. C., Ryu, S., Seo, J., Seok, S. Il., "High-performance photovoltaic perovskite layers fabricated through intramolecular exchange," Science.(May), science.aaa9272 (2015).

[15] Burschka, J., Pellet, N., Moon, S.-J., Humphry-Baker, R., Gao, P., Nazeeruddin, M. K.., Grätzel, M., "Sequential deposition as a route to high-performance perovskite-sensitized solar cells.," Nature 499(7458), 316-319 (2013).

[16] Jeon, N. J., Noh, J. H., Kim, Y. C., Yang, W. S., Ryu, S.., Seok, S. Il., "Solvent engineering for highperformance inorganic-organic hybrid perovskite solar cells.," Nat. Mater. 13(July), 1-7 (2014).

[17] Xiao, M., Huang, F., Huang, W., Dkhissi, Y., Zhu, Y., Etheridge, J., Gray-Weale, A., Bach, U., Cheng, Y. B., et al., "A Fast Deposition-Crystallization Procedure for Highly Efficient Lead Iodide Perovskite Thin-Film Solar Cells," Angew. Chemie - Int. Ed. (2014).

[18] Nie, W., Tsai, H., Asadpour, R., Blancon, J.-C., Neukirch, A. J., Gupta, G., Crochet, J. J., Chhowalla, M., Tretiak, S., et al., "High-efficiency solution-processed perovskite solar cells with millimeter-scale grains," Science (80-. ). 347(6221), 522-525 (2015).

[19] Fernandes, S. L., Véron, A. C., Neto, N. F. A., Nüesch, F. A., Dias da Silva, J. H., Zaghete, M. A.., Graeff, C. F. de O., "Nb2O5 hole blocking layer for hysteresis-free perovskite solar cells" (2016).

[20] Kogo, A., Numata, Y., Ikegami, M.., Miyasaka, T., "Nb2O5 Blocking Layer for High Open-circuit Voltage Perovskite Solar Cells," Chem. Lett. 44(6), 829-830 (2015).

[21] Zhang, Z., Yue, X., Wei, D., Li, M., Fu, P., Xie, B., Song, D.., Li, Y., “DMSO-based PbI2 precursor with PbCl2 additive for high efficient perovskite solar cells fabricated at low temperature," RSC Adv. 5(127), 104606$104611(2015)$. 